Teller, Christoph, Thomson, Jennifer A.. Gender Differences of Shoppers in the Marketing and Management of Retail Agglomerations. The Service Industries Journal. 32 (3), in print, DOI: 10.1080/02642069.2011.559725.

\title{
Gender Differences of Shoppers in the Marketing and Management of Retail Agglomerations
}

\author{
Christoph Teller ${ }^{\mathrm{I}}$, Jennifer A. Thomson ${ }^{\mathrm{II}}$ \\ University of Stirling, Stirling, United Kingdom
}

I, [corresponding author] Institute for Retail Studies, University of Stirling; Stirling FK9 4LA; United Kingdom; Tel: ++44 (0) 178646 6454; Fax: ++44 (0) 178646 5290; Email:

christoph.teller@stir.ac.uk;

II, Stirling Management School, University of Stirling; Stirling FK9 4LA; United Kingdom; Tel: + 44 (0) 1786 467412; Fax: + 44 (0) 1786 464745; Email: j.a.thomson@stir.ac.uk;

Christoph Teller is a senior lecturer in marketing in the Institute for Retail Studies, Stirling Management School, University of Stirling. He was previously assistant professor at the Vienna University of Economics and Business. Christoph's research interests are in the area of store (format) and agglomeration (format) choice/patronage, retail logistics and web-based research methodologies.

Jennifer A. Thomson is a lecturer in marketing in the Marketing Division at the University of Stirling. Her research interests are centred on decision making behaviour in various contexts including ethical and social marketing. 


\title{
Gender Differences of Shoppers in the Marketing and Management of Retail Agglomerations
}

\begin{abstract}
This paper aims to firstly, identify gender differences in perception and evaluation of retail agglomerations and secondly, discuss the implications of these differences for marketing and management. Based on a conceptual model 2,151 agglomeration shoppers were surveyed using interviewer-administered questionnaires. Structural equation modelling revealed that accessibility, parking and infrastructure are perceived differently between gender groups. The attractiveness in terms of satisfaction, retention proneness and patronage intention were also evaluated distinctively. Nevertheless, when examining the impact of the perceived attributes on the agglomeration attractiveness there was no difference. In both settings the retail tenant mix and the atmosphere are the main antecedents of attractiveness. Finally, an importance performance analysis offers managers a method for prioritising their marketing efforts considering gender differences.
\end{abstract}

Keywords: Retail agglomeration; marketing management; perception, gender; satisfaction; retention; patronage intention

\section{Introduction}

The central marketing and management of retail agglomerations is recognised as a crucial success factor in the competition amongst retail sites, including: shopping malls, shopping streets, town centres and retail parks (for example, Bennison et al., 2005; Howard, 1997). Managing and marketing such supra-store environments is considered challenging since prospective and existing shoppers of such agglomerations are a complex pool of clientele of individual tenants. Therefore, marketing issues of profiling, segmentation and importantly targeting are fraught with challenges (Balakrishnan, 2009). Agglomeration clientele are often treated similarly and only marginal acknowledgement is paid to the wants and needs of different shopper groups within this seemingly diverse group of consumers. However, to survive the increasing inter- and intra-format agglomeration competition (Leo \& Philippe, 2002; Teller, 2008), it becomes necessary to distinguish amongst certain consumer groups and subsequently target these by the use of marketing efforts (Rigopoulou et al., 2008).

A key distinguishing variable in terms of shopping behaviour is that of gender (see for example, Andrews et al., 2007; d'Astous, 2000; Grewal et al., 2003; Mitchell \& Walsh, 2004; O'Cass, 2004). Studies have shown that men and women perceive the shopping activity differently 
(Otnes \& McGrath, 2001), have different attitudes (Teller et al., 2008; Alreck \& Settle, 2002; Grewal et al., 2003) and subsequently behave in distinct ways when performing the shopping task (Sherman et al., 1997). Despite the recognised gender based differences in shopping behaviour limited research has focused on perceptual gender based differences on a retail agglomeration level. Yet this environment represents the most common shopping site. How people perceive the attributes of retail agglomerations, such as the tenant mix, parking facilities or the atmosphere, has a major impact on how such shopping sites are evaluated (Chebat et al., 2008; Hackett \& Foxall, 1994). This evaluation affects levels of satisfaction which impact on shoppers' intention (Szymanski \& Henard, 2001; Oliver, 1980; Fornell, 1992). This affects their willingness to patronise a shopping site and ultimately their patronage behaviour (Mägi, 2003). Accepting the established role of perception in affecting behaviour, this research specifically aims to achieve the following: (1) bring together the disparate discussions of gender differences in supra-store environments, (2) establish a conceptual framework to measure perceptual differences of retail agglomerations, (3) empirically evaluate gender differences of shoppers in heterogeneous agglomeration settings and finally (4) present implications for agglomeration managers to target their marketing management endeavours more gender specifically. 
The paper is structured as follows; first we provide an overview of how the literature has addressed gender based differentiation in shoppers' perceptions and behaviour, based on that we present a conceptual framework in which we embed three research propositions. The methodology of the empirical study is described and the results are subsequently presented. Finally, the findings are discussed with respect to the existing literature and conclusions for agglomeration managers and marketers are proposed. A limitation and outlook section concludes the paper.

\section{Literature review}

Shopping is stereotypically acknowledged as a female pursuit (Dholakia, 1999). The origins of this are rooted in traditional family structures involving clear gender based roles. Thus: male breadwinner and female homemaker, with a key task of the latter involving household shopping (Campbell, 1997). Consequently women have dominated the shopping landscape for decades. Today however, the shopping scene is far more diverse. Societal developments, including the increasing role of women in the paid workforce and the growing number of men adopting egalitarian gender roles (Engel et al., 1995) have contributed to a blurring of traditional household roles. Furthermore, ongoing gender role transcendence means that men are encroaching on traditionally female territory (e.g. skin care products) whilst women are actively engaging in male activities (e.g. lager drinking and watching sport) (Otnes \& McGrath, 2001). As a result of the gender mix in the shopping population, researchers are increasingly examining shopping behaviour and intentions in terms of gender based differences.

An overarching theme permeating gender and retail research is the acknowledgement of key attitudinal and behavioural differences between males and females in terms of shopping behaviour (Homburg \& Giering, 2001). Despite the increasing number of men in the shopping marketplace, research suggests that men do not enjoy shopping as much as women (Dholakia, 1999; Raajpoot et al., 2008) and generally have more negative attitudes towards the activity (Alreck \& Settle, 2002; 
Grewal et al., 2003) - a theme extending across a number of shopping contexts. These findings can, in part, be explained by appreciating differences in male and female shopping ideologies. Campbell (1997) claims that men have a tendency to be needs driven in terms of shopping rather than engaging in the behaviour for its intrinsic values. Therefore, shopping behaviour tends to be more targeted and purposeful. Conversely women are motivated to shop for more social reasons including interactions with family and friends (Dholakia, 1999) and for its intrinsic pleasure (Klein, 1998). Furthermore, the notion of 'shopping as recreation' has resulted in the development of shopping malls to meet a host of leisure needs including shopping, eating, drinking and cinema going, which women are shown to particularly enjoy (Mitchell \& Walsh, 2004). 
Research by Otnes and McGrath (2001) however, challenges the polarity of gender based research findings. The authors propose that men, who have transcended traditional gender role orientations, can combine hedonic or typically female associated shopping traits with more masculine tasks such as utilising technology and bargaining. This results in a challenge to traditional male shopping stereotypes. The appeal of bargains, in particular sales, to men is confirmed by Mitchell and Walsh (2004) highlighting this econometric aspect of their shopping behaviour.

Despite the variety of studies into gender differences in shopping discussed to this point, there is a lack of research examining consumers' perception of shopping stimuli on-site. Studies have focussed on issues of gender differences in shopping mall patronage, and mall navigation (e.g. Evans et al., 1996; Chebat et al., 2005; Dennis et al., 2005; Chebat et al., 2008; Raajpoot et al., 2008). Hart et al. (2007) in particular focused on the mediating role of gender examining the impact of enjoyment of the shopping experience on retail patronage in terms of regional shopping centres. Other research investigates gender perceptual differences in the on-line environment (Andrews et al., 2007). Nevertheless, little is known about how individuals perceive diverse kinds of multipurpose shopping locations and if gender based differences exist within this setting.

This research builds on previous gender based research in malls and online retail settings in a number of ways. First, by researching shoppers in retail agglomerations an extended view of the shopping landscape is accessed in both evolved (e.g., shopping streets) and created retail sites (e.g., shopping malls) (Teller, 2008). This shopping environment means there is greater variety in terms of the types of shoppers available creating a more diverse sampling frame. Second, this research seeks to determine if gender differences exist in how individuals perceive the attributes and evaluate attractiveness of agglomerations. Perception is recognised as an antecedent to behaviour (e.g. Theory of Planned Behaviour: Ajzen, 1991). As such, examining gender differences in perception of 
agglomerations will lead to a greater understanding of the agglomeration customer base and how they perceive the shopping environment around them which ultimately impacts on their behaviour.

\section{Conceptual framework and propositions}

Agglomeration managers are responsible for the marketing of their sites, which often means the manipulation and development of key stimuli or actionable attributes e.g. parking facilities, the retail and non-retail tenant mix and the atmosphere of the shopping site (Teller \& Reutterer, 2008; Hackett \& Foxall, 1994). How individuals interpret or perceive these stimuli will affect their attitudes and behaviour according to the Stimulus Organism Response (S-O-R) theory. The S-O-R framework (Donovan \& Rossiter, 1982) is rooted in the work of Mehrabian and Russell (1974). Typically the SO-R framework establishes that a set of attributes will impact on consumer perceptions and are external to the individual acting as the originator of the consumer behaviour process (Mazursky \& Jacoby, 1986). This model has been successfully applied in the retail environment (e.g. Sherman et al., 1997; Bell, 1999; Finn \& Lourviere, 1996) highlighting its suitability in this context. Empirical research into retail environment stimuli encompasses a range of factors including ambient conditions, design and social factors (McGoldrick \& Pieros, 1998). Common applications of the SO-R model are often based at a retail store level in order to understand the drivers of perception and behaviour of a particular store. For example, examinations of retail store perception have followed the premise that store image and information is cognitively processed by consumers leading to perception formation (Mazursky \& Jacoby, 1986). A substantial body of literature exists helping to explain the attributes and antecedents of consumer behaviour towards retail stores and shopping malls (for an overview see e.g. Teller \& Reutterer (2008)). In this context the number of empirical studies on town centres, shopping streets or other evolved retail agglomerations is still comparably limited (e.g., Nevin \& Huston, 1980; Bell, 1999; Leo \& Philippe, 2002). Only few findings have been generated in terms of gender differences in consumers' perception and behaviour in such evolved retail settings. 
In this study, gender differences in perception of agglomeration stimuli are investigated. Gender differences exist in other retail settings (e.g. Dholakia, 1999; Otnes \& McGrath, 2001) however, the agglomeration represents the most realistic shopping scenario as it involves multi-site and often multi-task activities (Arentze et al., 2005). Establishing if gender differences in perception of agglomeration stimuli exist will lead to an understanding of what potential stimuli will be most relevant to the agglomeration customer base in addition to contributing to the consumer behaviour literature in the area of retail agglomerations. It is proposed that the stimuli affecting consumers' perception in an agglomeration setting are influenced by agglomeration management when applying marketing instruments. The stimuli most pertinent to the agglomeration setting are represented in Figure 1. The conceptual framework within which we identify three different propositions is based on the relationship between stimulus and perception derived from the S-O-R framework.

\section{[Figure 1 about here]}

The Organism (see Figure 1) entails the consumer processing the stimuli and converting it into meaningful information which is used to evaluate the environment (Finn \& Lourviere, 1996). According to Mazursky and Jacoby (1986) the process of assimilating and evaluating this information causes a change in the emotional state of the consumer. This processing has an impact on behavioural outcome usually adopting a positive or negative consequence. Studies have shown that if the emotional state remains static then stimuli may have been discarded or remain but are inert (e.g. Donovan \& Rossiter, 1982; Sherman et al., 1997). Organism in this study is represented by two constructs, perception of agglomeration attributes and evaluation of agglomeration attractiveness. Attractiveness is operationalised as a multi-faceted, second order construct including the dimensions of satisfaction, retention proneness and patronage intentions (Teller \& Reutterer, 2008). The attractiveness in turn is affected by agglomeration attributes perceived by shoppers. The response is the end goal or resultant behaviour which occurs as a consequence of the stimulus and the organism 
processing. The particular focus of this research is based on the perceptions and evaluations of shoppers in response to stimuli, thus the S-O aspect of the S-O-R framework.

The perception of core agglomeration attributes - such as accessibility, parking, tenant mix, atmosphere, orientation or infrastructure and the evaluation of the overall attractiveness of an agglomeration can be seen as major drivers of patronage behaviour of shoppers (e.g. Finn \& Lourviere, 1996 or Teller \& Reutterer, 2008). The literature suggests that gender differences in the retail environment exist however diverse agglomeration environments is under-researched. Hence, this research will explore the moderating effect of gender differences in agglomerations supported by related research.

Women are shown to enjoy shopping more than men (Dholakia, 1999; Raajpoot et al, 2008). This enjoyment is evidenced in the characterisation of shopping as a leisure pursuit (Campbell, 1997) and means of social interaction (Otnes \& McGrath, 2001). Furthermore, the process of shopping is more effortful for women as they evaluate purchase decisions (Laroche et al., 2000) and derive pleasure from the shopping activity (Klein, 1998). As such, women are shown to be far more involved in the activity of shopping than men. This could suggest that factors in the agglomeration environment such as the retail tenant mix, atmosphere and infrastructure will be heightened for women as they seem more engaged in the shopping environment. With regards to men, studies have shown that some men do indeed transcend traditional shopping stereotypes (e.g. Otnes \& McGrath; Mitchell \& Walsh) however, dominant male shopping characteristics show men to be decisive and task orientated towards shopping (Campbell, 1997), coupled with a desire to complete the task in a short time frame showing a lack of patience for the activity (Bakewell \& Mitchell, 2004). These notable differences are likely to have an impact on how men perceive an agglomeration's attributes and attractiveness compared to women. Issues such as parking and orientation may be pertinent for men given their task orientated shopping habits. There are notable gender differences in shopping 
behaviour, which we believe will be evidenced in perceptual differences of environmental factors also. Given that women spend more time at shopping cites, are generally more 'engaged' in the shopping task and enjoy the activity of shopping more than men, we believe they will be more cognisant and afford more attention to the agglomeration attributes than men. While there is indeed indication that some agglomeration attributes may be more meaningful for men we believe women's perception of attributes will be stronger based on their altogether more engaged behaviour with regards to shopping. This leads to the following research proposition:

$\mathrm{P}_{1}$ : Female shoppers have different perceptions of retail agglomeration attributes (accessibility, parking, retail tenant mix, non-retail tenant mix, atmosphere, orientation and infrastructure) compared to men.

On a related note, how the agglomeration attractiveness is perceived is also likely to show a gender bias. In terms of retention proneness and patronage intention it would seem logical that women are more likely to evaluate these aspects of the agglomeration more positively than men. This is due to the nature of shopping behaviour discussed above. Women are shown to enjoy shopping more and spend more time performing the activity (Klein, 1998), therefore retention proneness, which captures concepts such pleasure and enjoyment in the shopping environment, are more likely to be viewed positively by women than men. Similarly patronage intention seeks a measure of likelihood to return to the agglomeration. It would seem that women are more likely than men to repatronise as this allows for more shopping, viewing and socialising which are identified as key enjoyable activities. For men, shopping is more task orientated (Bakewell \& Mitchell, 2004) therefore they are unlikely to want to stay in the shopping venue for longer than necessary. Thus, their retention proneness is likely to be less positive than women. The agglomeration attractiveness is measured by retention proneness, satisfaction and patronage intention. Given the positive disposition of women towards shopping duration and pleasure derived from the activity suggests there will be some differences 
between men and women's evaluation of agglomeration attractiveness as the following research proposition states:

$\mathrm{P}_{2}$ : Female shoppers evaluate the attractiveness of retail agglomeration (satisfaction, patronage intention and retention proneness) differently compared to men.

Raajpoot et al. (2008) explored gender differences in the relationship between shopping mall attributes and consumer shopping centre patronage. Similarly Homburg and Giering (2001) identified that gender partly moderates the relationship between satisfaction and loyalty in the car sales setting. Based on these findings and the case presented above regarding gender differences, we proposed the generic attributes applicable to distinct agglomeration settings will show different effects towards the attractiveness of agglomerations. Consequently this suggests the application of marketing instruments and the resulting perception of agglomerations' attributes will have different effects on the attractiveness evaluated by male and female shoppers. Thus, the following research proposition is offered:

$\mathrm{P}_{3}$ : The effects between perception of attributes and the evaluation of a retail agglomeration's attractiveness are different between female and male shoppers.

This set of research propositions focuses on two dimensions of gender differences evidenced in the literature. The first two $\left(\mathrm{P}_{1}\right.$ and $\left.\mathrm{P}_{2}\right)$ on the differences of how agglomerations are perceived and evaluated and the third one $\left(\mathrm{P}_{3}\right)$ explores differences in effects between attributes and attractiveness. Both dimensions are necessary since agglomeration management not only needs to know the present state of how their marketing instruments work (shoppers' current perceptions/evaluations) but also what can be done to change this state (effects or impact). 


\section{Methodology}

In order to test our propositions we surveyed the clientele of two competing supra-regional retail agglomerations, that is, a major shopping street and a peripheral shopping mall, over a period of three weeks. Both agglomeration sites are substantial and considered the largest in Europe in terms of sales and number of outlets. Regarding the tenant mix and sales both sites are comparable. Since the shopper groups are different according to the areas where they enter the agglomeration (Sudman, 1980) we (randomly) selected our informants every quarter of an hour at three clearly defined entrance points in each agglomeration. The number of selected respondents varied according to the forecasted number of visitors at different times of the day. Consequently, we only chose those visitors who had just started their shopping visit within the agglomeration. They were confronted with a standardised questionnaire administered by professional interviewers. Although the rejection rate was low the gender and estimated age was recorded from those visitors who were reluctant to participate and finally compared with the sample generated. No significant differences could be found $\left(\chi^{2}\right.$-test, $\left.p>.5\right)$. The interviews took place in rented areas of cafes and a specially adapted bus (in the shopping street).

The fundamental idea of the applied survey approach was to confront (actual) shoppers with questions in the context of a real shopping situation and within a real shopping environment (Bloch et al., 1994). As a consequence we focus on those informants having a high degree of knowledge about the retail sites and their shopping behaviour (Campbell, 1955). This approach enabled us to collect data on the actual shopping situation that is proposed to have a strong effect on the shopping behaviour on site (Hansen \& Jensen, 2009; Van Kenhove et al., 1999). Finally, two (random) samples of 1,071 shoppers in the shopping street and 1,080 shoppers of the shopping mall were retrieved. 


\section{Results}

\section{Characterisation of gender samples}

The deliberate choice of the survey approach and the focus on 'actual' shoppers resulted in the fact that the two samples do not represent the general population of the urban retail area. This is perhaps due to the fact that our respondents reflect role divisions within households in terms of shopping. Older and male citizens are therefore underrepresented in the two samples in terms of the general population. Nevertheless, the household related variables reflect the distributions of the household population. As a consequence, the two samples can be seen as representative of the clientele of the two agglomerations. Table 1 compares selected demographic variables between the two gender groups. The results show homogeneity across all demographic variables with the exception of individual income and number of working hours per week. Both male shopper groups have a significantly higher individual income and spend significantly more time at work compared to their female counterparts.

[Table 1 about here]

\section{Differences in perceiving agglomeration attributes $\left(P_{1}\right)$}

To measure perceptual differences, the seven most frequently cited attributes associated with agglomerations were identified (Teller \& Reutterer, 2008). The seven factors are of latent nature and consequently measured by at least two indicators derived from literature (see Appendix): 'Accessibility', 'Parking', 'Retail Tenant Mix', 'Non-Retail Tenant Mix', 'Atmosphere', 'Orientation' and 'Infrastructure'. In order to identify differences between perceptions we tested for variant latent mean structures of our (exogenous) measurement model. Prior to that, we (1) test the quality of construct measurement and (2) the variance of the measurement models of the two gender groups (in each agglomeration setting). 
The quality of the construct measurement was evaluated following the standard scale development and assessment procedure (e.g. Anderson \& Gerbing, 1988). Consequently, we calculated confirmatory factor analyses (CFA) for gender in each agglomeration setting. Positive factor loadings for all items, with indicator reliability greater than 0.4 and factor reliability higher than 0.6 for each of our (exogenous) factors in all of our four measurement models were identified (Bagozzi \& Baumgartner, 1994; Bagozzi \& Yi, 1988). Additionally, the average variance extracted (AVE) and the Fornell-Larcker Ratios were calculated showing how well the constructs are measured by their indicators (Anderson \& Gerbing, 1988; Fornell \& Larcker, 1981). In all cases the recommended threshold values are met $(\mathrm{AVE}>0.5$; FLR $<1)$ and thus show a satisfactory construct and discriminant validity (Bagozzi \& Yi, 1988).

By following the notions of Brown (2006) a multi-group-comparison test of the two measurement models in each setting was performed. The aim was to determine significant differences (variances) between the factor loadings and the indicator intercepts of the two gender groups. By applying a $\chi^{2}$ difference test between the baseline model - i.e. all parameters are allowed to vary freely across the two groups - and the constrained model - i.e. equality constraints on all factor loadings and intercepts are imposed. This test evaluates the null hypotheses that the constrained model is equal to the baseline model. Therefore, the differences of $\chi^{2}$-values $\left(\Delta \chi^{2}\right)$ of the two models are used as an indicator as to whether this hypothesis is to be accepted. In terms of the factor loadings the $\Delta \chi^{2}$ was $19.534(\Delta d f=13 ; p>.05)$ for the shopping street and $13.248(\Delta d f=13$; $p>.05)$ for the mall setting. In terms of the indicator intercepts the $\Delta \chi^{2}$ was $29.366(\Delta d f=20 ; p>.05)$ for the shopping street and $26.637(\Delta d f=20 ; p>.05)$ for the shopping mall. The null hypotheses can therefore be accepted. Thus, all factor loadings and indicator intercepts prove to be invariant (equal) across gender groups. Consequently a group comparison based on latent means of the constructs is interpretable (Brown, 2006). 
Given the invariance of factor loadings and intercepts of the gender specific measurement models this allows for testing invariances (=equality) of the latent mean structures between the two groups in each agglomeration. This test answers the question whether the latent means of each factor is different across groups. Thereby, one group needs to be defined as a reference group - in our case male shoppers - where the latent means are fixed to zero. By comparing the mean structure of the reference group with the one of the other group, that is, female shoppers, we identify (1) whether they are significantly different and (2) whether the latent mean value of the female group is higher or lower relative to our reference group. For further details regarding the applied analysis approach and the imposition of further parameter constraints when comparing the models see Byrne (2001).

Table 2 shows the significant differences of mean estimates between those of the reference male shopper groups $\left(\mu_{\curvearrowright}=0\right)$, and female groups (see $\mu_{\odot}$ ). First results show that the signs of mean values are the same in both agglomeration settings. This demonstrates that accessibility, the retail tenant mix and orientation of both the shopping street and the mall are perceived more positively by the female groups and less positively by the male shoppers, respectively. On the contrary parking, the non-retail tenant mix, atmosphere and infrastructure are seen more positively by the male group compared to the female group. Nevertheless, these differences are only significant for accessibility, parking and infrastructure in both settings. Additionally, the mean values differ significantly for the retail tenant mix in the shopping street setting and the orientation in the shopping mall setting. In total proposition $\mathrm{P}_{1}$ can be confirmed for all factors except the non retail tenant mix, the atmosphere the orientation in the shopping street setting, whereas we can confirm $\mathrm{P}_{1}$ except the two tenant mix factors and - again - atmosphere in the mall setting.

[Table 2 about here] 


\section{Differences in evaluating agglomerations attractiveness $\left(P_{2}\right)$}

Attractiveness is operationalised by three latent factors following Teller and Reutterer (2008), i.e. 'satisfaction', 'retention proneness' and 'patronage intentions', and again tested for invariances of latent mean structures (see Appendix), performed as above. Within this (endogenous) measurement model all factor loadings are positive and indicator reliability is greater than 0.4 . The composite reliability of each factor meets the requirement to be above 0.6 (Fornell \& Larcker, 1981) with the average variances extracted (AVE) in an acceptable range around 0.5 (Baggozzi \& Yi, 1988) and the Fornell-Larcker ratio below 1 . The $\chi^{2}$ difference test reveals no significant differences (=invariance) between the factor loadings (SST: $\Delta \chi^{2}=8.865(\Delta d f=5 ; p>.05)$; MAL: $\left.\Delta \chi^{2}=5.798(\Delta d f=5 ; p>.05)\right)$ and indicator intercepts (SST: $\Delta \chi^{2}=12.991(\Delta d f=8 ; p>.05)$; MAL: $\left.\Delta \chi^{2}=13.634(\Delta d f=8 ; p>.05)\right)$ and again the latent means comparison between the groups is interpretable.

The test of invariances of latent means structure can be seen from Table 2 with male shoppers selected as a reference group. As a result all three attractiveness factors are evaluated more positively by our female groups (see $\mu_{\odot}$ ). This difference is significant in all cases except satisfaction in the shopping street setting. Consequently, proposition $\mathrm{P}_{2}$ can be clearly confirmed except for satisfaction in the shopping street setting.

\section{Differences in effects between perceived attributes and evaluated attractiveness $\left(P_{3}\right)$}

To test the effect proposed between the perception of the seven exogenous factors and attractiveness, the invariances are examined. Attractiveness is measured as a second order construct $\left(\eta_{1}\right)$ which is operationalised by three latent factors: 'satisfaction', 'retention proneness' and 'patronage intention' $\left(\eta_{2}-\eta_{4}\right.$, see Figure 2). In order to compare the structural model, i.e. the set of effects between the exogenous and the endogenous factor, the factor loadings need to be invariant. We already know that the exogenous $\left(\xi_{1}-\xi_{7}\right)$ and endogenous measurement models $\left(\eta_{2}-\eta_{4}\right)$ are invariant. By again applying a $\Delta \chi^{2}$-Difference test we can show that the factor loadings of the second order constructs $\left(\beta_{1}-\beta_{3}\right)$ are 
invariant in both settings (SST: $\Delta \chi^{2}=1.588 ; \Delta d f=2 ; p>.05 ;$ MAL: $\Delta \chi^{2}=4.564 ; \Delta d f=2 ; p>.05$ ). As a consequence we can conclude that all our (first and second order) constructs are understood the same way by our female and male respondents in both settings.

The direction and size of effects in terms of standardised regression weights $(\gamma)$ are shown in Table 3. Prior to interpretation, global fit measures of the two baseline models are: the indices measuring the absolute (RMSEA <.08)), incremental (TLI and CFI >.9) and parsimonious fits (Normed $\chi^{2}(\mathrm{CMIN} / d f)(<3)$ meet the recommended thresholds therefore, the empirical data fit the proposed model to a satisfactory degree (see Table 3; Hu \& Bentler 1998, 1999; Anderson \& Gerbing, 1988).

Interpretation of the standardised regression coefficients show that the tenant mix and the atmosphere substantially $(\gamma>$.4) affect the agglomeration's attractiveness to a significant degree $(t$ values, $p<.05)$ in the shopping street sample. By testing for invariances between the single effects we identify a significantly higher impact of the tenant mix with male compared to female shoppers $\left(\Delta \chi^{2}>3.84 ; d f=1 ; p<.05\right)$. Compared to that, the results from the shopping mall samples show substantial, significant effects regarding the atmosphere only $(\gamma>.4)$. Additional significant but weaker effects can be identified for the retail and non retail tenant mix and the orientation ( $t$-values, $p<.05)$. The $\chi^{2}$ difference test reveals no significant differences between the effects in the two gender groups $\left(\Delta \chi^{2}<3.84 ; d f=1 ; p>.05\right)$. As a general result we see that the effects are merely homogenous between the two gender groups but are different in the two agglomeration settings. This leads to the clear rejection of proposition $\mathrm{P}_{3}$ in both agglomeration settings.

[Table 3 about here] 


\section{Discussion}

The results from this study illustrate that certain stimuli presented in the agglomeration setting are interpreted and perceived differently between genders. Elements of homogeneity have also been uncovered leading to marketing implications in terms of mass versus segmented agglomeration marketing. This study shows that men and women perceive convenience related attributes such as parking, accessibility and infrastructure differently. With, for example, accessibility perceived by women to be good yet for men it is perceived as comparably bad. We can therefore confirm Raajpoot et al.'s. (2008) and Hart et al.'s (2007) proposition that men - due to their lower willingness to spend time in agglomerations - are more critical about attributes related to the logistics of shopping efforts. Overall, these nuances in perceptual differences help understand the shopper base better, leading to more accurate marketing of the agglomeration.

Unlike the findings of Helgesen and Nesset (2010) who focused on a grocery store context demonstrating no significant gender difference in satisfaction, our findings indicate a higher satisfaction and willingness to stay and return to both agglomerations amongst female shoppers. This result may partly be explained through gender differences regarding the activity of shopping as men often shop on a needs driven basis whilst women are shown to shop for the intrinsic pleasure (Klein, 1998; Hart et al., 2007). In addition the agglomeration setting offers the social dimension of shopping including, eating, drinking and cinema going, which women are shown to particularly enjoy (Mitchell \& Walsh, 2004). Furthermore Evans et al. (1996) and Raajpoot et al. (2008) note that women working outside of the home view shopping as recreation whilst women working at home regard it as part of their role.

Surprisingly, those attributes perceived differently by female and male shoppers play no significant role in enhancing agglomeration's attractiveness. This leads to the conclusion that they are perceived differently with respect to accessibility, parking and infrastructure in terms of their 
attractiveness but the attractiveness as such can be enhanced by the same factors, i.e. the retail tenant mix and the atmosphere, in both settings and for both groups. Confirming the findings of McGoldrick and Pieros (1998) and Teller (2008), the tenant mix and atmosphere are the main determinants of agglomeration attractiveness. In line with the findings from Reimers and Clulow (2004) we also see that orientation and non-retail tenant mix show low but still significant effects in the mall setting and can therefore be considered to increase attractiveness for both groups too.

It can be concluded that we are faced with a considerable heterogeneity of perceptions whereby men and women are shown to perceive aspects of the agglomeration environment distinctly. Despite these identified differences they do not translate into differences in terms of effects. This is illuminating for researchers and practitioners alike. Despite the widely recognised gender differences in shopping, in order to appeal to the agglomeration customer and make this shopping site attractive, both genders will respond to the two key factors of the tenant mix and atmosphere.

\section{Practical implications}

To make these findings more meaningful for practical application we combine the various results and discussion around our three research propositions to illustrate more explicitly the role of gender differences in this setting. We follow the notions of Johnson and Gustaffson (2000) who suggest the use of an importance-performance analysis to identify those attributes that contribute most to a change of attractiveness (i.e., impact or standardised effect). In addition to this the analysis considers the current perception of agglomeration attributes i.e., performance index or weighted means of items behind each factor. Factor score weights which are provided by the structural equation modelling output are used as weighting values. Figure 2 and 3 depict the two-dimensional performance-impact matrices. These matrices are divided into quadrants using means of all included impact and performance scores as separating values. The position of each factor suggests the application of norm strategies, e.g. improve or maintain performance. 
In both settings the focus of improvement (high impact/low performance) should be laid on the factor of atmosphere for both gender groups. Thus, agglomeration managers should seek to improve and nourish the atmosphere by actively sending out pleasant visual and sensory stimuli like appealing store fronts, decoration, events, pleasant music or odour. In terms of the shopping mall this is also true for the factor orientation whereas the improvement potential is higher for the male shopper group.

Again in both settings the performance level and impact level is high for the retail tenant mix. That suggests improving or at least maintaining the performance in this area. In terms of the shopping street the retail tenant mix shows a significantly greater potential and thus should be prioritised to improve the attractiveness for the male shopper group. Despite the significant differences in terms of perception of accessibility, infrastructure and parking no differences in terms of prioritising can be suggested. In this area either the high performance should be maintained or despite the low performance level - fewer resources should be invested due to the low impact on the attractiveness of both agglomerations.

[Figure 2 about here]

[Figure 3 about here]

It can be concluded that it is necessary to interpret the results from measuring differences in the perception of attributes $\left(\mathrm{P}_{1}\right.$ and $\mathrm{P}_{2}$; performance index) and the differences in effects between gender groups $\left(\mathrm{P}_{3}\right.$; impact index $)$ in combination in order to make the right prioritisation decisions. The interpretation of each of the results independent from each other might result into misleading conclusions. For example, the accessibility of the shopping street is perceived significantly different between the two gender groups and show in both settings high performance scores. Nevertheless, neither has the potential to change the overall attractiveness substantially. The tenant mix in the 
shopping mall shows a very high performance level in general. Although the impact of this factor is considerable it proves to be more difficult to raise the performance by the agglomeration management as it currently shows a high performance level. Therefore further investment in this area is futile.

In summation, the position within the two by two matrix and the attached norm strategies can help to understand the combination of both the status quo, i.e. performance, and the potential to change this status in the future, i.e. impact. An application of this analysis procedure by considering different consumer segments - in our case gender - supports agglomeration managers and marketers to make the right decisions in order to address segment specific differences and thus support differentiated marketing endeavours.

\section{Limitations and future research}

We specifically selected supra-regional agglomerations formats representing those which can be found in most capital cities. Consequently the clientele of such sites are different to those of other smaller and more regional formats. Based on Evanschitzky et al. (2007) a replication of this study is suggested in order to reveal characteristic, attitudinal and behaviour differences of female and male shopper groups within regional shopping streets or malls, factory outlet centres, central shopping malls or strip centres.

Reflecting on Van Kenhove et al. (1999), the applied survey approach targeted actual shoppers serving as our respondents. This approach includes several shortcomings including the strong influence of the shopping task and shopping situation at the time of the interview. It could be interesting to compare our results with studies simply drawing a representative sample from the general population and have the interview conducted in the respondents' homes. 
This study adopted an exploratory approach to examine gender differences in various aspects of perception, evaluation and behaviour in two agglomeration settings. Future research should focus on perception differences regarding each attribute or each dimension of in more detail.

Our findings stress the importance of gender as an important moderator for agglomeration patronage behaviour. Building on Evans et al. (1996) and Raajpoot et al. (2008) a fruitful future study could explore other moderators such as age, educational level, income, household size or shopping orientation to reveal perhaps further reasons for perceptual differences in the agglomeration setting.

\section{References}

Ajzen, I. (1991). The theory of planned behaviour. Organizational Behaviour and human Decision Processes, 50, 179-211.

Alreck, P., \& Settle, R.B. (2002). Gender effects on internet, catalogue and store shopping. Journal of Database Management, 9, 150-162.

Anderson, J.C., \& Gerbing, D.W. (1988). Structural equation modelling in practice: A review and recommended two-step approach. Psychological Bulletin, 103, 411-423.

Andrews, L., Kiel, G., Drennan, J., Boyle, M.V., \& Weerawardena, J. (2007). Gendered perceptions of experiential value in using web-based retail channels, European Journal of Marketing, 41, 640-658.

Arentze, T.A., Oppewal, H., \& Timmermans, H.J.P. (2005). A multipurpose shopping trip model to assess retail agglomeration effects. Journal of Marketing Research, 42, 109-115.

Bagozzi, R.P., \& Baumgartner, H. (1994). The evaluation of structural equation models and hypothesis testing. In R.P. Bagozzi (Ed.), Principles of marketing research, (pp. 386-422). Cambridge: Blackwell. 
Bagozzi, R.P., \& Yi., Y. (1988). On the evaluation of structural equation models. Journal of the Academy of Marketing Science, 16, 74-94.

Bakewell, C., \& Mitchell, V.-W. (2004). Male consumer decision-making styles. International Review of Retail, Distribution and Consumer Research, 14, 223-40.

Balakrishnan, M.S. (2009). Strategic branding of destinations: A framework. European Journal of Marketing, 43, 611-629.

Bell, S.J. (1999). Image and consumer attraction to intraurban retail areas: An environmental psychology approach. Journal of Retailing and Consumer Services, 6, 67-78.

Bennison, D., Warnaby, G., \& Davies, B.J. (2005). Retailing and the marketing of urban places: A UK perspective. International Review of Retail, Distribution and Consumer Research, 15, 191215.

Bloch, P.H. (1994). The shopping mall as consumer habitat. Journal of Retailing, 70, 23-42.

Brown, T.A. (2006). Confirmatory factor analysis for applied research. New York: Guildford Press.

Byrne, B.M. (2001). Structural equation modelling with AMOS. Basic concepts, applications, and programming. London: Lawrence Erlbaum Associates Mahwah.

Campbell, C. (1997). Shopping, pleasure and the sex war. In P. Falk, \& C. Campbell (Eds.), The shopping experience, (pp. 166-176). London: Sage.

Campbell, D.T. (1955). The informant in quantitative research. American Journal of Sociology, 60, $339-342$.

Chebat, J-C., Gelinas-Chebat, C., \& Therrien, K. (2005). Lost in a mall, the effects of gender, familiarity with the shopping mall and the shopping values on shoppers' way finding process. Journal of Business Research, 58, 1590-1598.

Chebat, J-C., Gelinas-Chebat, C., \& Therrien, K. (2008). Gender-related wayfinding time of mall shoppers. Journal of Business Research, 61, 1076-1082. 
d'Astous, A. (2000). Irritating aspects of the shopping environment. Journal of Business Research, 49, 149-156.

Dholakia, R.R. (1999). Going shopping: key determinants of shopping behaviours and motivations. International Journal of Retail and Distribution Management, 27, 154-165.

Donovan R.J., \& Rossiter, J.R. (1982). Store atmosphere: An environmental psychology approach. Journal of Retailing, 58, 34-57.

Engel, J.F., Blackwell, R.D., \& Miniard, P.W. (1995). Consumer behaviour. Fort Worth, TX: The Dryden Press.

Evans, K.R., Christiansen, T., \& Gill, J.D. (1996). The impact of social influence and role expectations on shopping centre patronage intentions. Journal of the Academy of Marketing Science, 24, 208-218.

Evanschitzky, H., Baumgarth, C., Hubbard, R., \& Armstrong, J.S. (2007). Replication research's disturbing trend. Journal of Business Research, 60, 411-415.

Finn, A., \& Louviere, J. J. (1996). Shopping center image, consideration, and choice: Anchor store contribution. Journal of Business Research, 35, 241-251.

Fornell C. (1992). A national customer satisfaction barometer: The Swedish experience. Journal of Marketing, 56, 6-21.

Fornell, C., \& Larcker, D.F. (1981). Evaluating structural equation models with unobservable variables and measurement error. Journal of Marketing Research, 18, 39-40.

Grewal, D., Baker, J., Levy, M., \& Voss, G.B. (2003). The effects of wait expectations and store atmosphere evaluations on patronage intentions in service-intensive retail stores. Journal of Retailing, 79, 259-268.

Hackett, P.M.W., \& Foxall, G.R. (1994). A factor analytic study of consumers' location specific values: A traditional high street and a modern shopping mall. Journal of Marketing Management, 10, 163-178. 
Hansen, T., \& Jensen, J.M. (2009). Shopping orientation and online clothing purchases: The role of gender and purchase situation. European Journal of Marketing, 43, 1154-1170.

Hart, C., Farrell, A.M., Stachow, G., Reed, G., Cadogan, J.W. (2007). Enjoyment of the shopping experience: Impact on customers' repatronage intentions and gender influence. Service Industries Journal, 27, 583-604.

Helgesen, Ø., \& Nesset, E (2010). Gender, store satisfaction and antecedents: A case study of a grocery store. Journal of Consumer Marketing, 27, 114-126.

Homburg, C., \& Giering, A. (2001). Personal characteristics as moderators of the relationship between customer satisfaction and loyalty - an empirical analysis. Psychology and Marketing, 18, 43-66.

Howard, E. (1997). The management of shopping centres: Conflict or collaboration? The International Review of Retail, Distribution and Consumer Research, 7, 263-285.

Hu, L-T., \& Bentler, P.M. (1998). Fit indices in covariance structure modelling: Sensitivity to underparameterized model misspecification. Psychological Methods, 3, 424-53.

Hu, L-T., \& Bentler, P.M. (1999). Cutoff criteria for fit indexes in covariance structure analysis: Conventional criteria versus new alternatives. Structural Equation Modeling, 6, 1-55.

Johnson, M.D., \& Gustafsson, A. (2000). Improving customer satisfaction, loyalty and profit. San Francisco: Jossey-Bass.

Klein, L.R. (1998). Evaluating the potential of interactive media through a different lens: Search versus experience goods. Journal of Business Research, 41, 195-203.

Laroche, M., Saad, G., Cleveland, M., \& Browne, E. (2000). Gender differences in information search strategies for a Christmas gift. Journal of Consumer Marketing, 17, 500-524.

Leo, P.Y., \& Philippe, J. (2002). Retail centres: location and consumer's satisfaction. Service Industries Journal, 22, 122-146. 
Mägi, A.W. (2003). Share of wallet in retailing: The effects of customer satisfaction, loyalty cards and shopper characteristics. Journal of Retailing, 79, 97-106.

Mazursky, D., \& Jacoby, J. (1986). Exploring the development of store images. Journal of Retailing, $62,145-165$.

McGoldrick, P.J., \& Pieros, C.P. (1998). Atmospheres, pleasure and arousal: The influence of response moderators. Journal of Marketing Management, 14, 173-197.

Mehrabian, A., \& Russel, J. A. (1974). An approach to environmental psychology. Cambridge (MA): MIT-Press.

Mitchell, V-W., \& Walsh, G. (2004). Gender differences in German consumer decision-making styles. Journal of Consumer Behaviour, 3, 331-346.

Nevin, J.R., \& Houston, M.J. (1980). Image as a component of attraction to intraurban shopping areas. Journal of Retailing, 56, 77-93.

Noble, S.M., Griffith, D.A., \& Adjei, M.T. (2006). Drivers of local merchant loyalty: Understanding the influence of gender and shopping motives. Journal of Retailing, 82, 177-188.

O'Cass, A. (2004). Fashion clothing consumption: antecedents and consequences of fashion clothing involvement. European Journal of Marketing, 38, 869-882.

Oliver, R.L. (1980). A cognitive model of the antecedents and consequences of satisfaction decisions. Journal of Marketing Research, 17, 460-469.

Otnes, C., \& McGrath, M.A. (2001). Perceptions and realities of male shopping behavior. Journal of Retailing, 77, 111-137.

Raajpoot, N.A., Sharma, A., \& Chebat, J-C. (2008). The role of gender and work status in shopping centre patronage. Journal of Business Research, 61, 825-833.

Reimers, V., \& Clulow, V. (2004). Retail concentration: A comparison of spatial convenience in shopping strips and shopping centres. Journal of Retailing and Consumer Services, 11, 207221. 
Rigopoulou, I.D., Tsiotsou, R.H., \& Kehagias, John D. (2008). Shopping orientation-defined segments based on store-choice criteria and satisfaction: an empirical investigation. Journal of Marketing Management, 24, 979-995.

Sherman, E., Mathur, A., \& Smith, R.B. (1997). Store environment and consumer purchase behavior: mediating role of consumer emotions. Psychology and Marketing, 14, 361-378.

Sudman, S. (1980). Improving the quality of shopping center sampling. Journal of Marketing Research, 17, 423-431.

Szymanski, D.M., \& Henard, D.H. (2001). Customer satisfaction: A meta-analysis of the empirical evidence. Journal of the Academy of Marketing Science, 29, 16-35.

Teller, C. (2008). Shopping streets versus shopping malls - determinants of agglomeration format attractiveness from the consumers' point of view. International Review of Retail, Distribution and Consumer Research, 18, 381-403.

Teller, C., \& Reutterer, T. (2008). The evolving concept of retail attractiveness: what makes retail agglomerations attractive when customers shop at them? Journal of Retailing and Consumer Services, 15, 127-143.

Teller, C., Reutterer, T., \& Schnedlitz, P. (2008). Hedonic and utilitarian shopper types in evolved and created retail agglomerations. International Review of Retail, Distribution and Consumer Research, 18, 283-309.

Van Kenhove, P., de Wulf, K., \& van Waterschoot, W. (1999). The impact of task definition on store-attribute saliences and store choice. Journal of Retailing, 75, 125-137.

\section{Appendix}

[Appendix about here] 
Figure 1. Conceptual framework

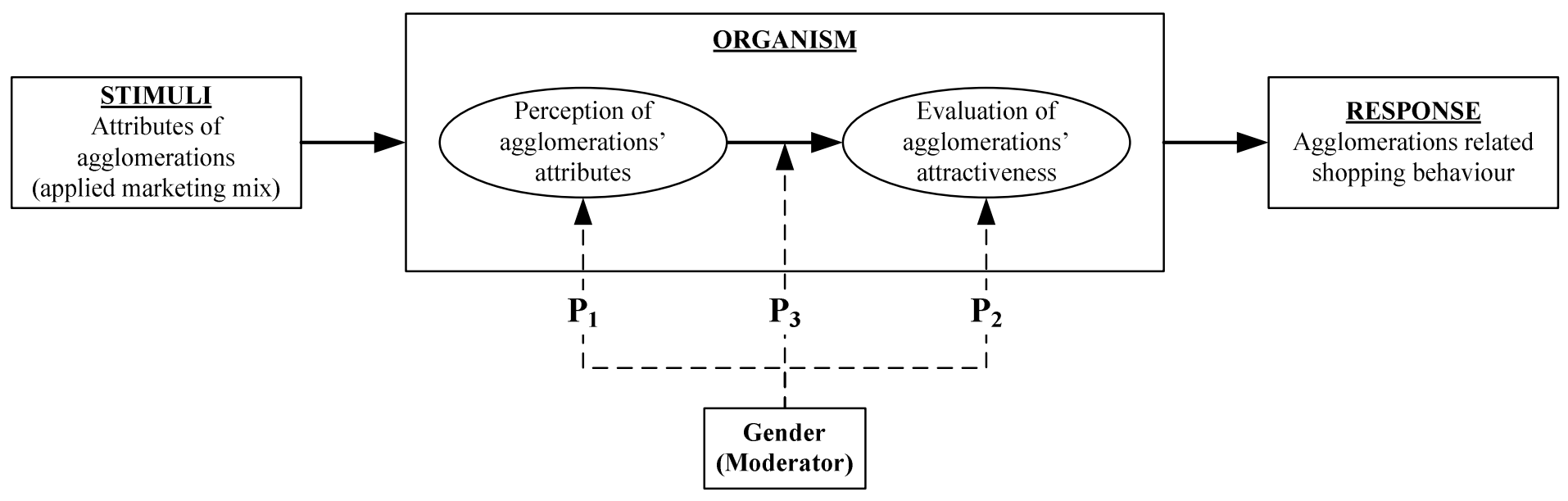


Figure 2. Impact-performance matrix for the shopping street

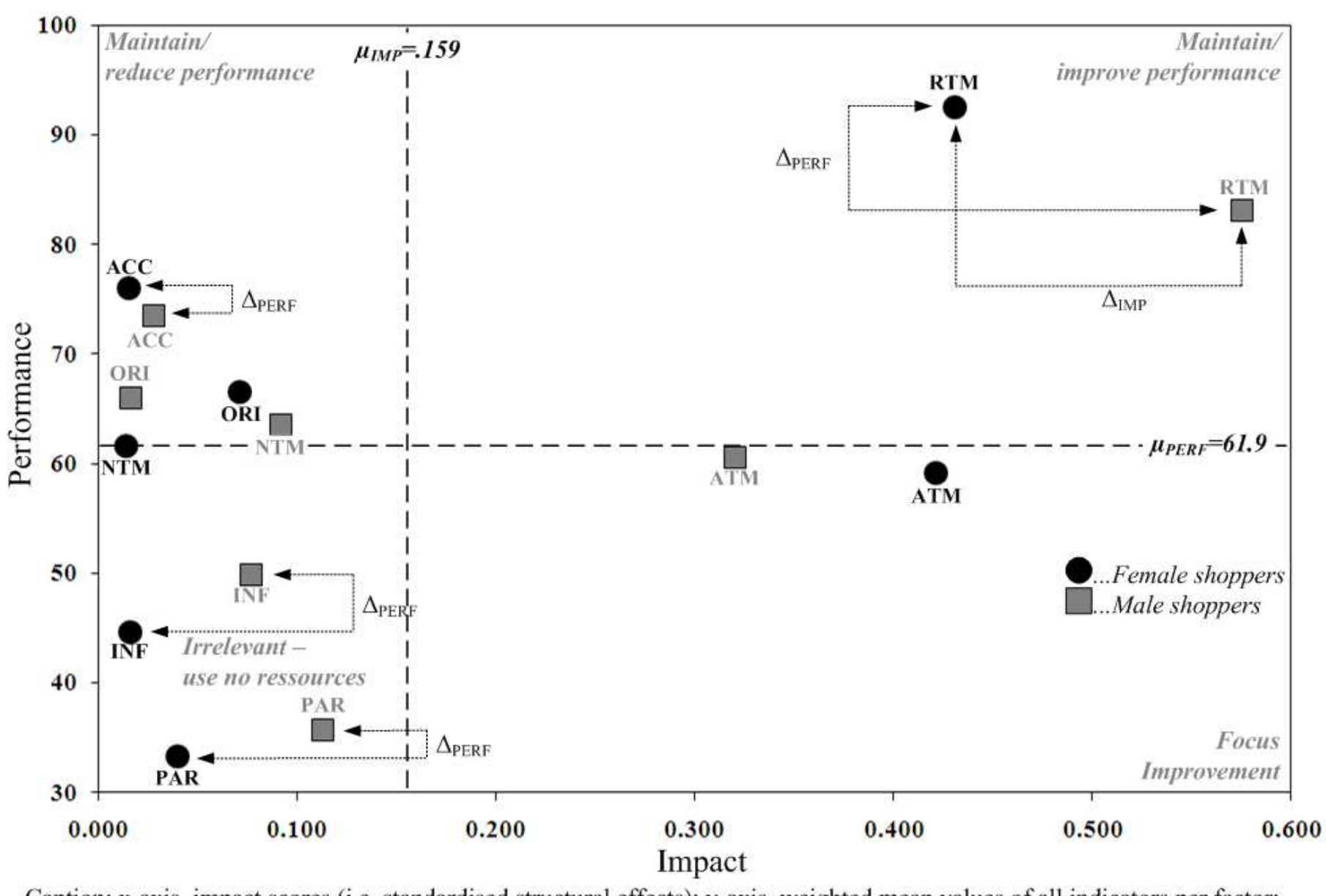

Caption: $\mathrm{x}$-axis, impact scores (i.e. standardised structural effects); $\mathrm{y}$-axis, weighted mean values of all indicators per factor; ACC, accessibility; PAR, parking; RTM, retail tenant mix; NTM, non retail tenant mix; ATM, atmosphere; ORI, orientation; INF, Infrastructure; $\mu_{I M P}$, mean value of all impact scores; $\mu_{P E R F}$, mean value of all performance scores; $\Delta_{\text {PERF }}$, significant difference between performance scores (see latent means comparison); $\Delta_{\mathrm{IMP}}$, significant difference between impact scores (see comparison of structural effects); 
Figure 3. Impact-performance matrix for the shopping mall

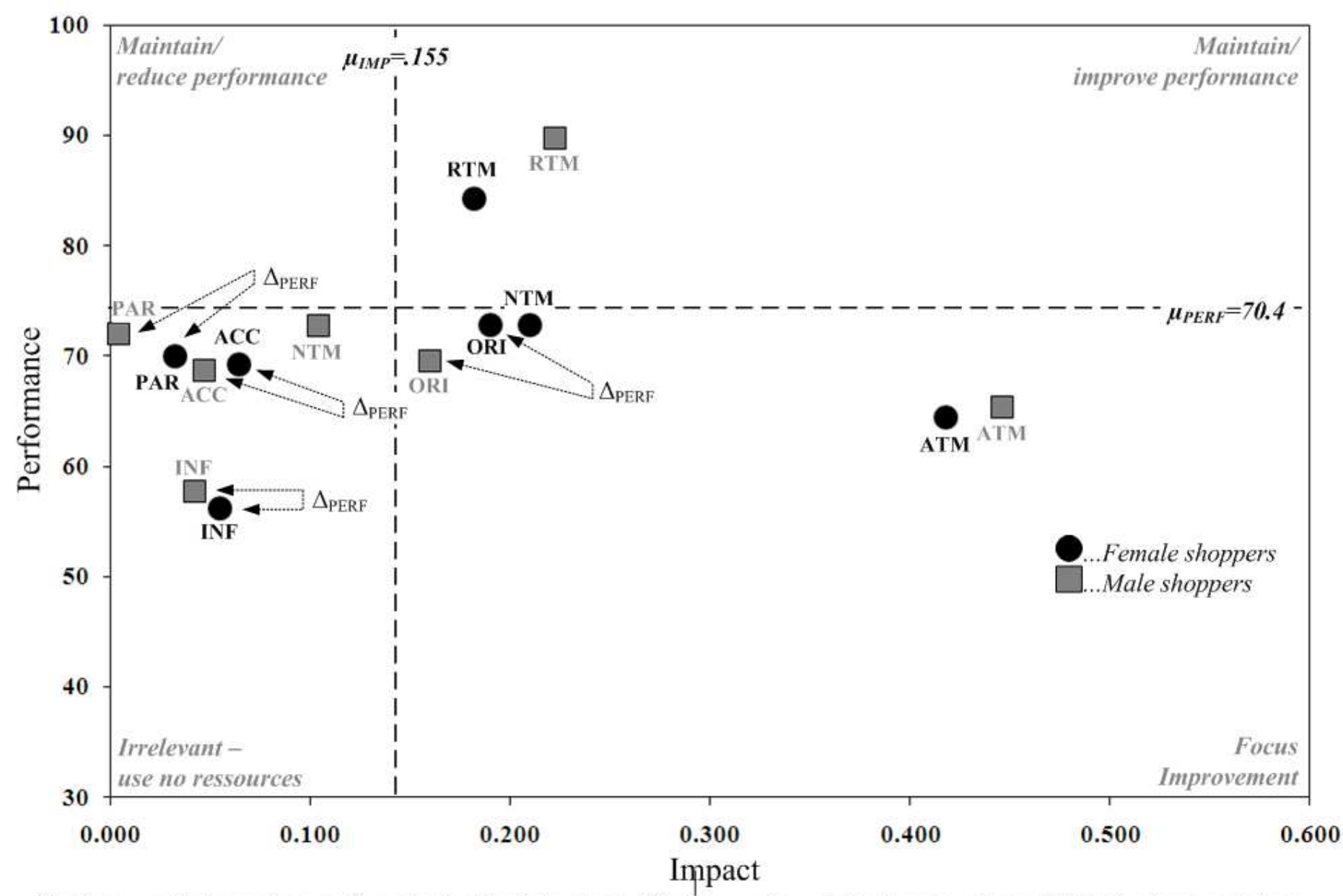

Caption: $\mathrm{x}$-axis, impact scores (i.e. standardised structural effects); $\mathrm{y}$-axis, weighted mean values of all indicators per factor; ACC, accessibility; PAR, parking; RTM, retail tenant mix; NTM, non retail tenant mix; ATM, atmosphere; ORI, orientation; INF, Infrastructure; $\mu_{I M P}$, mean value of all impact scores; $\mu_{P E R F}$, mean value of all performance scores; $\Delta_{\mathrm{PERF}}$, significant difference between performance scores (see latent means comparison); 
Table 1. Demographic characterisation

\begin{tabular}{|c|c|c|c|c|c|c|}
\hline \multirow{2}{*}{$\begin{array}{l}\text { Agglomeration } \\
\text { Characterisation } \\
\text { Gender [\%] }\end{array}$} & \multicolumn{2}{|c|}{ Shopping street $(\mathrm{n}=1,071)$} & \multirow[t]{2}{*}{$\Delta$} & \multicolumn{2}{|c|}{ Shopping mall $(\mathrm{n}=1,080)$} & \multirow[t]{2}{*}{$\Delta$} \\
\hline & $q=62.5$ & $\hat{\sigma}=37.5$ & & $q=61.0$ & $\hat{\sigma}=39.0$ & \\
\hline Age (years) $[\mu(\sigma)]$ & $\begin{array}{c}27.2 \\
(13.3)\end{array}$ & $\begin{array}{c}27.5 \\
(12.2)\end{array}$ & $-{ }^{\dagger \dagger}$ & $\begin{array}{c}30.1 \\
(14.0)\end{array}$ & $\begin{array}{c}30.3 \\
(13.0)\end{array}$ & $-{ }^{\dagger \dagger}$ \\
\hline $\begin{array}{l}\text { Individual Income } \\
\text { (EUR) }[\mu(\sigma)]\end{array}$ & $\begin{array}{c}780.3 \\
(706.4)\end{array}$ & $\begin{array}{c}1,108.1 \\
(1.092 .0)\end{array}$ & $* * * \dagger$ & $\begin{array}{c}972.0 \\
(826.5)\end{array}$ & $\begin{array}{c}1,427.7 \\
(1.376 .3)\end{array}$ & $* * * \dagger$ \\
\hline $\begin{array}{l}\text { Household income } \\
(\text { EUR) }[\mu(\sigma)]\end{array}$ & $\begin{array}{c}2,348.3 \\
(1,809.5)\end{array}$ & $\begin{array}{c}2,724.7 \\
(2,247.3)\end{array}$ & $-t^{\dagger+}$ & $\begin{array}{l}2,639.6 \\
(1.633 .4)\end{array}$ & $\begin{array}{l}3,022.6 \\
(2255.4)\end{array}$ & $-\dagger$ \\
\hline $\begin{array}{l}\text { Education (Top 3) } \\
{[\%]^{1}}\end{array}$ & $\begin{array}{l}\text { S: } 30.2 \\
\text { A: } 51.9 \\
\text { U: } 16.4\end{array}$ & $\begin{array}{l}\mathrm{S}: 34.8 \\
\mathrm{~A}: 45.5 \\
\mathrm{U}: 17.9\end{array}$ & $-{ }^{\dagger}$ & $\begin{array}{l}\text { S: } 45.7 \\
\text { A: } 43.9 \\
\text { U: } 10.5\end{array}$ & $\begin{array}{l}\text { S: } 46.8 \\
\text { A: } 39.7 \\
U: 13.1\end{array}$ & $--^{\dagger}$ \\
\hline Marital status [\%] & $\begin{array}{l}\text { Single: } 72.2 \\
\text { Partner: } 27.8\end{array}$ & $\begin{array}{l}\text { Single: } 72.9 \\
\text { Partner: } 27.1\end{array}$ & $-\dagger$ & $\begin{array}{l}\text { Single: } 55.7 \\
\text { Partner: } 44.2\end{array}$ & $\begin{array}{l}\text { Single: } 60.3 \\
\text { Partner: } 39.7\end{array}$ & $--^{\dagger}$ \\
\hline $\begin{array}{l}\text { Number of persons per } \\
\text { households }[\mu(\sigma)]\end{array}$ & $\begin{array}{c}2.6 \\
(1.5)\end{array}$ & $\begin{array}{c}2.7 \\
(1.8)\end{array}$ & $-\dagger \dagger$ & $\begin{array}{c}2.8 \\
(1.4)\end{array}$ & $\begin{array}{c}2.9 \\
(1.9)\end{array}$ & $-\dagger$ \\
\hline $\begin{array}{l}\text { Number of children } \\
\text { per household }[\mu(\sigma)]\end{array}$ & $\begin{array}{c}.6 \\
(1)\end{array}$ & $\begin{array}{l}.5 \\
(1)\end{array}$ & $-{ }^{\dagger \dagger}$ & $\begin{array}{l}.7 \\
(1)\end{array}$ & $\begin{array}{l}.7 \\
(1)\end{array}$ & $-\dagger$ \\
\hline $\begin{array}{l}\text { Number of cars } \\
\text { available in household } \\
{[\mu(\sigma)]}\end{array}$ & $\begin{array}{c}1 \\
(1)\end{array}$ & $\begin{array}{l}1.1 \\
(1)\end{array}$ & $-\dagger \dagger$ & $\begin{array}{l}1.5 \\
(1)\end{array}$ & $\begin{array}{l}1.7 \\
(1)\end{array}$ & $-\dagger \dagger$ \\
\hline $\begin{array}{l}\text { Working hours per } \\
\text { week }[\mu(\sigma)]\end{array}$ & $\begin{array}{c}18.6 \\
(18.5)\end{array}$ & $\begin{array}{c}24.8 \\
(22.5)\end{array}$ & $* * * \dagger$ & $\begin{array}{c}21.5 \\
(20.3) \\
\end{array}$ & $\begin{array}{c}30.1 \\
(21.6) \\
\end{array}$ & $* * * \dagger+$ \\
\hline $\begin{array}{l}\text { Caption: } \mu \text {, mean value; } \\
\text { Whitney Test; EUR, E } \\
\text { significant difference } \\
\text { 'widowed' and 'divorce }\end{array}$ & $\begin{array}{l}\text { andard dev } \\
\text { o, female; } \\
\text { ); } 1 \text {, the r } \\
\text { artner inclu }\end{array}$ & $\begin{array}{l}\Delta, \text { differe } \\
\text { significant } \\
\text { ccounts for } \\
\text { narried' an }\end{array}$ & $\begin{array}{l}\text { betv } \\
\text { ffere }\end{array}$ & $\begin{array}{l}\text { gender grou } \\
p<.001 \quad \text { (** } \\
\text { chool; 2, si } \\
\text { partnership }\end{array}$ & $\begin{array}{l}\dagger, \chi^{2} \text {-Test; } \dagger \\
<.01, *, p<. \dagger \\
\text { e includes t }\end{array}$ & $\begin{array}{l}\text { Mann- } \\
-, \text { no }\end{array}$ \\
\hline
\end{tabular}


Table 2. Latent means comparison - perceived attributes and evaluated attractiveness

\begin{tabular}{|c|c|c|c|c|c|c|}
\hline \multirow{2}{*}{$\begin{array}{l}\text { Agglomeration } \\
\text { Attribute }\end{array}$} & \multicolumn{3}{|c|}{ Shopping street $(n=1,071)$} & \multicolumn{3}{|c|}{ Shopping mall $(n=1,080)$} \\
\hline & $\mu_{\text {里 }}$ & S.E. & $\Delta$ & $\mu_{\text {o }}$ & S.E. & $\Delta$ \\
\hline \multicolumn{7}{|c|}{ Exogenous measurement model } \\
\hline Accessibility & 3.029 & .098 & $* * *$ & .589 & .108 & $* * *$ \\
\hline Parking & -.891 & .068 & $* * *$ & -.256 & .088 & $* *$ \\
\hline Retail Tenant Mix & .182 & .051 & $* * *$ & .074 & .041 & - \\
\hline Non Retail Tenant Mix & -.065 & .084 & - & -.067 & .078 & - \\
\hline Atmosphere & -.147 & .093 & - & -.106 & .088 & - \\
\hline Orientation & .074 & .071 & - & .141 & .055 & $* *$ \\
\hline Infrastructure & -.379 & .084 & $* * *$ & -.204 & .094 & $*$ \\
\hline \multicolumn{7}{|c|}{ Endogenous measurement model } \\
\hline Satisfaction & .081 & .062 & - & .164 & .064 & $*$ \\
\hline Retention proneness & .388 & .121 & $* * *$ & .412 & .118 & $* * *$ \\
\hline Patronage intention & .422 & .142 & $* *$ & .551 & .168 & $* *$ \\
\hline
\end{tabular}

Notions: (latent) mean are fixed to zero for the reference (male) groups $\left(\mu_{\delta}=0\right)$; the $\mu_{\text {o }}$ need to be interpreted relative to zero; Global fit of the baseline models: Exogenous model: SST: CFI=.901; TLI: .889; RMSEA:.056; MAL: CFI=.931; TLI: .921; RMSEA=.047; Endogenous model: SST: CFI=.956; TLI: .944; RMSEA:.052; MAL: CFI=.973; TLI: .965; RMSEA=.044;

Caption: $\mu_{\rho}$, mean estimate for the female groups relative to the reference group (=male shoppers); S.E, Standard error of means; $\Delta$, Significant difference; ***, significant difference (Critical ratio value $(=\mu /$ S.E. $)>1.92), p<.001 ; * *, p<.01 ; *, p<.05 ;-$, no significant difference between means of groups) 
Table 3. Effects between perceived attributes and evaluated attractiveness

\begin{tabular}{|c|c|c|c|c|c|c|}
\hline \multirow{2}{*}{$\begin{array}{l}\text { Agglomeration } \\
\text { Parameter }\end{array}$} & \multicolumn{3}{|c|}{ Shopping street $(n=1,071)$} & \multicolumn{3}{|c|}{ Shopping mall $(n=1,080)$} \\
\hline & $q$ & $\hat{0}$ & $\Delta \chi^{2}(\Delta d f=1)$ & 우 & $\hat{0}$ & $\Delta \chi^{2}(\Delta d f=1)$ \\
\hline$\gamma_{11}$ & .015 & .028 & .964 & .064 & .047 & 2.038 \\
\hline$\gamma_{21}$ & .040 & .113 & 1.406 & .032 & .004 & .035 \\
\hline$\gamma_{31}$ & $.431 * * *$ & $.575 * * *$ & $4.744^{*}$ & $.182 * * *$ & $.222 * * *$ & .025 \\
\hline$\gamma_{41}$ & .014 & .092 & .733 & $.210 * * *$ & $.104^{*}$ & 1.270 \\
\hline$\gamma_{51}$ & $.421 * * *$ & $.320 * * *$ & .543 & $.418 * * *$ & $.446 * * *$ & 2.790 \\
\hline$\gamma_{61}$ & .071 & .016 & .081 & $.190 * *$ & $.160^{*}$ & .028 \\
\hline$\gamma_{71}$ & .016 & .077 & .331 & .055 & .042 & .005 \\
\hline $\begin{array}{l}\Delta \chi^{2} \text { (for all gammas } \\
\text { equal across } \\
\text { subgroups }\end{array}$ & \multicolumn{3}{|c|}{$\Delta \chi^{2}(\Delta d f=7)=8.118$} & \multicolumn{3}{|c|}{$\Delta \chi^{2}(\Delta d f=7)=6.665$} \\
\hline Global fit measures & \multicolumn{3}{|c|}{$\begin{array}{c}\text { CFI=.930; TLI: } .917 ; \\
\text { RMSEA:.036; } \chi^{2} / d f: 2.352\end{array}$} & \multicolumn{3}{|c|}{$\begin{array}{c}\text { CFI=.928; TLI:.915; } \\
\text { RMSEA:.040; } \chi^{2} / d f: 2.741\end{array}$} \\
\hline $\begin{array}{l}\text { Caption: } \Delta \chi^{2}, \text { results } 1 \\
\text { exogenous factors }\left(\xi_{1}\right.\end{array}$ & $\begin{array}{l}\text { om } \mathrm{Chi}^{2} \text { ( } \\
7 \text { ) and en }\end{array}$ & $\begin{array}{l}\text { ence test; } \\
\text { lous facto }\end{array}$ & $\begin{array}{l}p<.001 ; * \\
\text { l) }\end{array}$ & $01 ; *, 1$ & $\gamma$, gamm & ects between \\
\hline
\end{tabular}


Appendix. Measurement models and local fit measures

\begin{tabular}{|c|c|c|c|c|c|c|c|c|}
\hline \multirow{3}{*}{$\begin{array}{r}\text { Exogenous measurement models } \\
\text { Agglomeration format/Gender group } \\
\text { Measures/indices } \\
\text { (latent) Factor } \\
\text { Indicator }\end{array}$} & \multirow{2}{*}{\multicolumn{2}{|c|}{$\begin{array}{r}\text { Shopping street } \\
+(\mathrm{n}=669)\end{array}$}} & & 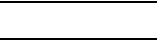 & \multicolumn{4}{|c|}{ Shopping mall } \\
\hline & & & & 402) & & $=659)$ & & \\
\hline & $\mu(\sigma)$ & $\begin{array}{c}\alpha / \rho \\
\text { AVE/FLR }\end{array}$ & $\mu(\sigma)$ & $\begin{array}{c}\alpha / \rho \\
\text { AVE/FLR }\end{array}$ & $\mu(\sigma)$ & $\begin{array}{c}\alpha / \rho \\
\text { AVE/FLR }\end{array}$ & $\mu(\sigma)$ & $\begin{array}{c}\alpha / \rho \\
\text { AVE/FLR }\end{array}$ \\
\hline $\begin{array}{l}\text { Accessibility }\left(\xi_{1}\right) \\
\text { You can easily get to } \ldots \text { a }^{\text {a }} \\
\text { You can get to } \ldots \text { quickly. } \\
\text { You can get to } \ldots \text { without problems. }{ }^{\text {a }} \\
\end{array}$ & $\begin{array}{l}5.7(1.9) \\
5.2(2.1) \\
5.8(1.7)\end{array}$ & $\begin{array}{l}.91 / .92 \\
.78 / .02\end{array}$ & $\begin{array}{l}5.5(2.0) \\
5.1(2.1) \\
5.6(2.0)\end{array}$ & $\begin{array}{l}.91 / .92 \\
.79 / .08\end{array}$ & $\begin{array}{l}5.2(2.1) \\
5.0(2.2) \\
5.2(2.0)\end{array}$ & $\begin{array}{l}.96 / .96 \\
.89 / .11\end{array}$ & $\begin{array}{l}5.2(2.0) \\
5.0(2.1) \\
5.2(1.9)\end{array}$ & $\begin{array}{l}.94 / .95 \\
.85 / .12\end{array}$ \\
\hline $\begin{array}{l}\text { Parking }\left(\xi_{2}\right) \\
\ldots \text { has always enough free parking lots. }{ }^{\mathrm{a}} \\
\ldots \text { offers different parking facilities sufficiently. }{ }^{\mathrm{a}} \\
\text { The ... can be reached from the parking lots easily. }{ }^{\mathrm{a} \dagger} \\
\text { The ... can be reached from the parking lots savely. }{ }^{\dagger}{ }^{\dagger} \\
\text { The ... can be reached from the parking lots savely and quickly. } .^{\mathrm{a} \dagger}\end{array}$ & $\begin{array}{l}2.9(1.4) \\
2.9(1.6) \\
4.0(1.6)\end{array}$ & $\begin{array}{l}.67 / .68 \\
.50 / .32\end{array}$ & $\begin{array}{l}2.0(1.5) \\
3.2(1.7) \\
4.2(1.6)\end{array}$ & $\begin{array}{l}.68 / .62 \\
.48 / .42\end{array}$ & $\begin{array}{l}4.3(2.0) \\
5.2(1.8) \\
5.8(1.4)\end{array}$ & $\begin{array}{l}.74 / .75 \\
.51 / .38\end{array}$ & $\begin{array}{l}4.1(2.0) \\
5.2(1.8) \\
5.7(1.4)\end{array}$ & $\begin{array}{l}.70 / .72 \\
.48 / .22\end{array}$ \\
\hline $\begin{array}{l}\text { Retail tenant mix }\left(\xi_{3}\right) \\
\ldots \text { has a broad range of retail stores. } \\
\ldots \text { has an attractive range of retail stores. }{ }^{\text {a }} \\
\text { Many well-known retail stores are in } \ldots \text { a }^{\mathrm{a}}\end{array}$ & $\begin{array}{r}6.2(1.1) \\
6.0(1.2) \\
6.4(.9) \\
\end{array}$ & $\begin{array}{l}.78 / .81 \\
.61 / .34\end{array}$ & $\begin{array}{l}6.2(1.0) \\
5.9(1.2) \\
6.2(1.0) \\
\end{array}$ & $\begin{array}{l}.76 / .78 \\
.55 / .45\end{array}$ & $\begin{array}{c}6.6(.8) \\
6.4(1.0) \\
6.6(.8) \\
\end{array}$ & $\begin{array}{l}.79 / .80 \\
.58 / .32\end{array}$ & $\begin{array}{r}6.5(.8) \\
6.3(1.1) \\
6.4(1.0) \\
\end{array}$ & $\begin{array}{l}.80 / .82 \\
.60 / .48\end{array}$ \\
\hline $\begin{array}{l}\text { Non-retail tenant mix }\left(\xi_{4}\right) \\
\ldots \text { has a broad range of bars and restaurants. }{ }^{\mathrm{a}} \\
\ldots \text { offers a broad range of entertainment facilities. }{ }^{\mathrm{a}}\end{array}$ & $\begin{array}{l}5.1(1.5) \\
4.3(1.4) \\
\end{array}$ & $\begin{array}{l}.70 / .70 \\
.54 / .38 \\
\end{array}$ & $\begin{array}{l}5.2(1.4) \\
4.3(1.4) \\
\end{array}$ & $\begin{array}{l}.71 / .71 \\
.55 / .45\end{array}$ & $\begin{array}{l}5.7(1.4) \\
4.9(1.8) \\
\end{array}$ & $\begin{array}{l}.69 / .63 \\
.49 / .40 \\
\end{array}$ & $\begin{array}{l}5.6(1.4) \\
5.0(1.7) \\
\end{array}$ & $\begin{array}{l}.71 / .71 \\
.56 / .52 \\
\end{array}$ \\
\hline $\begin{array}{l}\text { Atmosphere }\left(\xi_{5}\right) \\
\text { The odour is not disturbing in .... } \\
\text { The air is pleasant in .... }{ }^{\dagger} \\
\text { The temperature is pleasant in .... } \\
\text { The light is pleasant in .... } \\
\text { It is always clean in .... } \\
\text { The architecture is appealing in ..... } \\
\text { There is a good mood in .... } \\
\text { The atmosphere is pleasant in .... }\end{array}$ & $\begin{array}{l}4.5(1.6) \\
4.6(1.5) \\
\end{array}$ & $\begin{array}{l}.85 / .90 \\
.78 / .37\end{array}$ & $\begin{array}{l}4.6(1.5) \\
4.6(1.5) \\
\end{array}$ & $\begin{array}{l}.85 / .87 \\
.71 / .27\end{array}$ & $\begin{array}{l}4.8(1.5) \\
4.9(1.5) \\
\end{array}$ & $\begin{array}{l}.89 / .91 \\
.79 / .28\end{array}$ & $\begin{array}{l}4.8(1.4) \\
4.9(1.5)\end{array}$ & $\begin{array}{l}.89 / .92 \\
.79 / .27\end{array}$ \\
\hline $\begin{array}{l}\text { Orientation }\left(\xi_{6}\right) \\
\text { You can move around without problems in .... }{ }^{a \dagger} \\
\text { You can move around safely and quickly in } \ldots{ }^{\dagger}{ }^{\dagger} \\
\text { You can easily orientate yourself within .... } \\
\text { Stores are arranged clearly in .... }\end{array}$ & $\begin{array}{l}4.1(1.7) \\
5.4(1.6) \\
5.0(1.6)\end{array}$ & $\begin{array}{l}.72 / .90 \\
.75 / .39\end{array}$ & $\begin{array}{l}4.5(1.7) \\
5.6(1.4) \\
4.8(1.5)\end{array}$ & $\begin{array}{l}.71 / .67 \\
.51 / .88\end{array}$ & $\begin{array}{l}5.4(1.5) \\
5.3(1.7) \\
5.4(1.6)\end{array}$ & $\begin{array}{l}.79 / .81 \\
.60 / .49\end{array}$ & $\begin{array}{l}5.3(1.5) \\
5.3(1.7) \\
5.1(1.6)\end{array}$ & $\begin{array}{l}.76 / .78 \\
.55 / .53\end{array}$ \\
\hline $\begin{array}{l}\text { Infrastructure }\left(\xi_{7}\right) \\
\text { There are enough toilets in .... } \\
\text { There are enough cash dispensers in .... } \\
\text { There are enough recreational areas in .... }\end{array}$ & $\begin{array}{l}3.2(1.7) \\
4.6(1.6) \\
3.6(1.8)\end{array}$ & $\begin{array}{l}.67 / .62 \\
.49 / .83\end{array}$ & $\begin{array}{l}3.5(1.7) \\
4.8(1.6) \\
3.8(1.8) \\
\end{array}$ & $\begin{array}{l}.69 / .64 \\
.51 / .97 \\
\end{array}$ & $\begin{array}{l}4.4(1.8) \\
4.4(1.7) \\
4.1(1.8) \\
\end{array}$ & $\begin{array}{l}.75 / .76 \\
.51 / .58 \\
\end{array}$ & $\begin{array}{l}4.7(1.7) \\
4.6(1.7) \\
4.1(1.8) \\
\end{array}$ & $\begin{array}{l}.72 / .72 \\
.48 / .63\end{array}$ \\
\hline
\end{tabular}




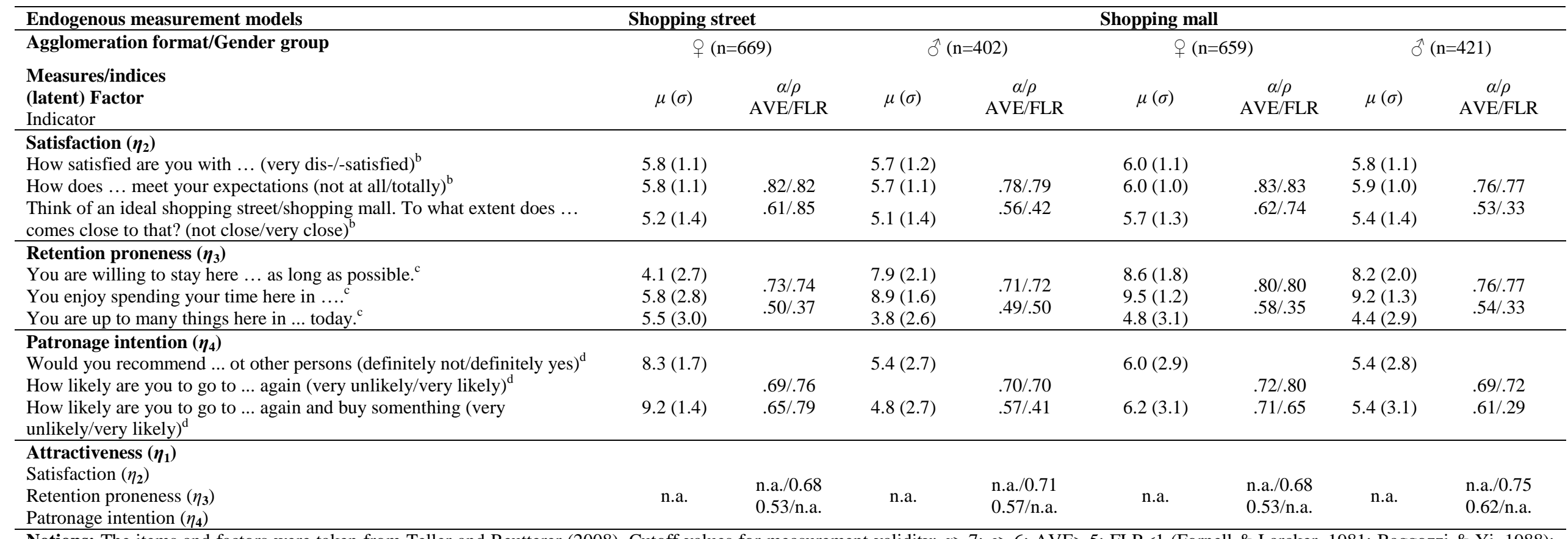

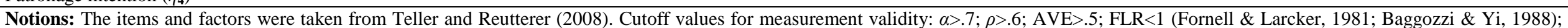

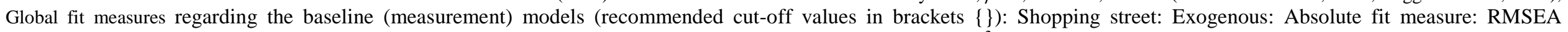

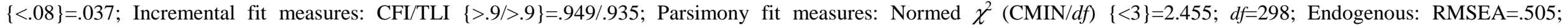

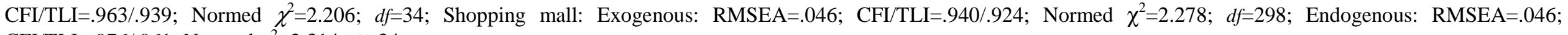

CFI/TLI=.976/.961; Normed $\chi^{2}=2.314 ; d f=34$;

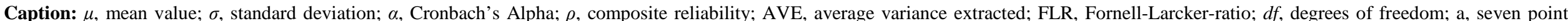

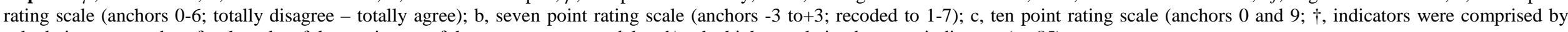
calculating mean values for the sake of the parsimony of the measurement model and/or the high correlation between indicators $(r>.85)$; 